Check for updates

Cite this: J. Anal. At. Spectrom., 2017 32,2200

Received 9th August 2017

Accepted 8th September 2017

DOI: $10.1039 / c 7 j a 00273 d$

rsc.li/jaas

\section{Simultaneous speciation of chromate, arsenate, molybdate and vanadate in alkaline samples by HPLC-ICP-MS at different concentration levels of vanadate $\dagger$}

\author{
Ana Drinčić, (D) ab Janez Ščančar, (DD ab Tea Zuliani, (D) ab Irena Nikolić (D) ${ }^{c}$ \\ and Radmila Milačič (iD *ab
}

\begin{abstract}
Flay ash, cement and electric arc furnace (EAF) dust are frequently mixed in building composites. From them, chromium (Cr), arsenic (As), molybdenum (Mo) and vanadium ( $\mathrm{V}$ ) may be leached. Concentrations of $\mathrm{V}$ in leachates may be significantly higher than those of $\mathrm{Cr}$, As and Mo, making simultaneous speciation analysis particularly difficult. In this work, a high performance liquid chromatography inductively coupled plasma mass spectrometry (HPLC-ICP-MS) procedure was used for simultaneous speciation of chromate, arsenate, molybdate and vanadate. First, the behaviour of $\mathrm{Cr}$, As, Mo and $\mathrm{V}$ species in different oxidation states was studied during their separation under acidic $(\mathrm{pH} 5)$ and alkaline ( $\mathrm{pH} 12)$ conditions. At alkaline $\mathrm{pHs}$ chromate, arsenate, molybdate and vanadate were simultaneously separated and eluted at retention times from 390 to $450 \mathrm{~s}, 230$ to $270 \mathrm{~s}, 340$ to $430 \mathrm{~s}$ and 270 to $380 \mathrm{~s}$, respectively and detected on-line by ICP-MS, recording $\mathrm{m} / \mathrm{z} 52,75,95$ and 51 , respectively. When $\mathrm{V}$ species were leached in significantly higher concentrations than $\mathrm{Cr}$, Mo and As, their detection was possible at the low abundance $(0.25 \%){ }^{50} \mathrm{~V}$ isotope, which is also the mass of the ${ }^{50} \mathrm{Cr}$ isotope (abundance 4.345\%), due to selective separation between $\mathrm{V}$ and $\mathrm{Cr}$ species. Good repeatability of measurement (RSD better than $\pm 3.0 \%$ ) and quantitative elution of elemental species (column recoveries 99-105\%) were obtained. Finally, the procedure was applied in the simultaneous speciation analysis of chromate, arsenate, molybdate and vanadate in highly alkaline aqueous leachates from composites consisting of fly ash, cement and EAF dust that contained a wide range of concentrations of vanadate.
\end{abstract}

\section{Introduction}

High performance liquid chromatography (HPLC) coupled to an inductively coupled plasma mass spectrometry (ICP-MS) detector is a powerful tool for the elemental speciation analysis in a variety of environmental and biological samples. ${ }^{1-3}$ Despite the possibility of multielemental detection, speciation analysis by HPLC-ICP-MS is usually carried out separately for the species of a particular element. Simultaneous speciation analysis of two or more elements is possible only if the chemical species of different elements behave similarly during the analysis. Multielemental speciation analysis, which is scarcely documented, requires such chromatographic conditions that enable selective separation and quantitative elution of all

${ }^{a}$ Department of Environmental Sciences, Jožef Stefan Institute, Jamova 39, 1000 Ljubljana, Slovenia. E-mail: radmila.milacic@ijs.si; Tel: +38614773560

${ }^{b}$ Jožef Stefan International Postgraduate School, Jamova 39, 1000 Ljubljana, Slovenia 'University of Montenegro, Faculty of Metallurgy and Technology, Džordža Vašingtona bb, 81000 Podgorica, Montenegro

$\dagger$ Electronic supplementary information (ESI) available. See DOI: 10.1039/c7ja00273d elemental species of interest. Morita et al., ${ }^{\mathbf{4}}$ for example, developed a sensitive method for the simultaneous speciation of arsenic (As) and antimony ( $\mathrm{Sb}$ ) in hot spring water and fish samples by HPLC-ICP-MS. By the use of a C30 reversed phase column and careful optimization of the chromatographic conditions, it was possible to separate eight As (As(III), As(v), monomethylarsonic acid (MMAA), dimethylarsinic acid (DMAA), arsenobetaine (AB), arsenocholine (AsC), trimethylarsine oxide (TMAO) and tetramethylarsonium (TeMA)) and two antimony species ( $\mathrm{Sb}(\mathrm{III})$ and $\mathrm{Sb}(\mathrm{v}))$. Bednar et al. ${ }^{5}$ performed separation of oxoanions of tungsten (W), molybdenum (Mo) and phosphorus (P) on an anion-exchange Dionex AS-11 chromatographic column. Coupling of this column to ICP-MS enabled simultaneous speciation analysis of tungstate, molybdate, and phosphate at the sub $\mu \mathrm{g} \mathrm{L}^{-1}$ concentration levels in ground water and aqueous soil extracts. Wolf et al. ${ }^{6}$ modified the analytical method that was previously developed for the determination of $\mathrm{Cr}(\mathrm{III})$ and $\mathrm{Cr}(\mathrm{vI})$ by HPLC-ICP-MS. The usage of a silica based Brownlee C8 column and the same chromatographic conditions as for the Cr speciation allowed the simultaneous determination of $\mathrm{As}(\mathrm{III}), \mathrm{As}(\mathrm{v}), \mathrm{Se}(\mathrm{IV}), \mathrm{Se}(\mathrm{VI}), \mathrm{Cr}(\mathrm{III})$, 
and $\mathrm{Cr}(\mathrm{vI})$ in leachates from ash and soil affected by wildfires. Simultaneous speciation analysis of $\mathrm{As}, \mathrm{Sb}$ and thallium (Tl) species (As(III), As(v), $\mathrm{Sb}(\mathrm{III}), \mathrm{Sb}(\mathrm{v}), \mathrm{Tl}(\mathrm{I})$, and $\mathrm{Tl}(\mathrm{III})$ ) in river water samples was reported in which an anion-exchange Dionex IonPac AS-7 column coupled to ICP-MS was used. ${ }^{7}$ The analytical procedure was also optimized for the simultaneous speciation of $\mathrm{As}(\mathrm{III}), \mathrm{As}(\mathrm{v})$, monomethylarsenic acid (MMA), dimethylarsenic acid (DMA), Cr(III) and $\mathrm{Cr}(\mathrm{VI})$, and $\mathrm{Cd}(\mathrm{II})$ in water samples on an anion-exchange Hamilton PRP-X100 column with ICP-MS detection. ${ }^{8}$ In our group, a method developed for the determination of $\mathrm{Cr}(\mathrm{vI})$ in different sample matrices by anion-exchange HPLC-ICP-MS ${ }^{9-12}$ was modified and adapted so that it was possible to simultaneously determine concentrations of chromate, molybdate, tungstate and vanadate in welding fume extracts. ${ }^{13}$

It is important to stress that chromatographic conditions for the multielemental speciation analysis must be optimized so that chemical species of a given element are selectively separated on a stationary phase and quantitatively eluted from the column, while there is no need for selective separation of species of different elements, as long as their $\mathrm{m} / \mathrm{z}$ ratios monitored by ICP-MS do not overlap. At the same time, it is desired that chemical species of the elements analysed are present at similar concentration levels. However, this is not always the case when real environmental samples like leachates from building composites are analysed. Re-use of industrial waste byproducts in different building materials is an acceptable alternative in waste management, ${ }^{\mathbf{1 4 - 1 6}}$ only if such materials possess appropriate technical characteristics ${ }^{\mathbf{1 7}}$ and their use is environmentally safe. ${ }^{6}$ For evaluation of the release of toxic substances from building composites, different leaching tests are applied, ${ }^{\mathbf{1 8 - 2 0}}$ using mainly demineralised water as the leaching solution. Although speciation is of crucial importance for the estimation of elemental toxicity and mobility, ${ }^{1-3}$ information on the extent of leaching of chemical species of elements from the re-cycled building materials is still scarce and was mainly focused on speciation of $\mathrm{Cr}$ in aqueous samples from different leachability tests. ${ }^{17,19,21-23}$ Among pollutants in wastes from thermal power plants and steel-making industry, $\mathrm{Cr}$, As, Mo and vanadium (V) are usually present in concentrations of environmental concern. ${ }^{20}$ In our group, environmental impacts of building composites, which were $98 \%$ composed of a mixture of fly ash (80\%) and cement (20\%), with the remaining $2 \%$ being electric arc furnace (EAF) dust, were evaluated by the use of leachability tests over a period of 6 months. ${ }^{20}$ Due to the presence of $\mathrm{Ca}(\mathrm{OH})_{2}$ and $\mathrm{CaCO}_{3}$, the aqueous leachates were highly alkaline. Hence, the HPLC-ICP-MS procedure, already used in the analysis of welding fume alkaline extracts, was successfully applied for the simultaneous determination of chromate, molybdate and vanadate. ${ }^{13}$ This study revealed that in the first 4 days after the start of the experiment, chromate, molybdate and vanadate were leached in comparable amounts, while after 9 days, more intensive leaching of vanadate, in amounts 20 to 30 times higher than those of chromate and molybdate, was observed, making simultaneous speciation analysis very difficult. Therefore, in leachates that contained high $\mathrm{V}$ concentrations, speciation analysis of $\mathrm{V}$ was carried out separately in additionally diluted samples. The experimental data also showed that As was leached in relatively high concentrations. Consequently, As speciation was needed for the evaluation of its environmental impacts.

In the present work, novel approaches to the simultaneous speciation analysis of Cr, As, Mo and V by HPLC-ICP-MS, using an anion-exchange Mono Q column in real world samples, were investigated. Separated elemental species were monitored at $\mathrm{m} /$ $z$ 52, 75 and 95, for $\mathrm{Cr}$, As and Mo, respectively, while for $\mathrm{V}$ species at $m / z 51$ and 50. Chromatographic conditions were optimized so that selective separation of $\mathrm{V}$ and $\mathrm{Cr}$ species was achieved, enabling detection of high concentrations of $\mathrm{V}$ at its low abundance $(0.25 \%$ (ref. 24$)){ }^{50} \mathrm{~V}$ isotope, which is also the mass of the ${ }^{50} \mathrm{Cr}$ isotope (abundance $4.345 \%$ (ref. 24)). Once developed and optimized, the analytical procedure was applied in the simultaneous speciation analysis of chromate, arsenate, molybdate and vanadate in highly alkaline samples of aqueous leachates from building composites, which were made up of various mixtures of fly ash, cement and EAF dust and were left in the leaching solution for different times.

\section{Experimental}

\subsection{Instrumentation}

Concentrations of elements were determined by ICP-MS on an Agilent (Tokyo, Japan) 7900 instrument. Chromatographic separations of elemental species were performed on an Agilent series 1200 quaternary pump equipped with a model 7725i Rheodyne sample injection valve (Cotati, CA, USA) fitted with a $0.2 \mathrm{~mL}$ injection loop. For the separation of $\mathrm{Cr}$, As, Mo and $\mathrm{V}$ species a strong anion-exchange fast protein liquid chromatography (FPLC) column, Mono Q HR 5/5 (GE Healthcare BioSciences, Uppsala, Sweden) (column dimensions $5 \times 50 \mathrm{~mm}$, matrix polystyrene/divinyl benzene, $\mathrm{pH}$ stability 2-12, particle size $10 \mu \mathrm{m}$ ) was used. The outlet of the chromatographic column was directly connected to the Miramist nebuliser and Scott-type spray chamber of the ICP-MS instrument. Nickel sampler and skimmer cones were used with 1.0 and $0.4 \mathrm{~mm}$ orifices, respectively. To control the stability of the mass spectrometer, the eluent was spiked (post-column addition) with internal standards of $100 \mu \mathrm{g} \mathrm{L}^{-1}$ germanium (Ge), scandium (Sc), rhodium (Rh) and indium (In). Data were treated with Agilent MassHunter software. Data processing was based on the peak area. Experimental working conditions for ICP-MS were optimized for plasma robustness and adequate sensitivity using a high matrix introduction (HMI) system. Samples analysed contained high amounts of carbonates and sulphur compounds, while $\mathrm{NaCl}$ that was used as the eluent in the chromatographic separation contained chloride ions, which contribute to the formation of polyatomic interferences. To eliminate severe polyatomic interferences of ${ }^{34} \mathrm{~S}^{16} \mathrm{O}^{+}$at $m / z 50$, ${ }^{34} \mathrm{~S}^{16} \mathrm{O}^{1} \mathrm{H}^{+},{ }^{35} \mathrm{Cl}^{16} \mathrm{O}^{+}$and ${ }^{38} \mathrm{Ar}^{13} \mathrm{C}^{+}$at $m / z 51,{ }^{35} \mathrm{Cl}^{16} \mathrm{O}^{1} \mathrm{H}^{+},{ }^{40} \mathrm{Ar}^{12} \mathrm{C}^{+}$ and ${ }^{34} \mathrm{~S}^{18} \mathrm{O}^{+}$at $m / z 52$ and ${ }^{40} \mathrm{Ar}^{35} \mathrm{Cl}^{+}$at $m / z 75,{ }^{25}$ high energy collision mode (HECM) was applied. ${ }^{9}$ The use of HMI reduced the sample aerosol transport, and enabled direct analysis of separated elemental species in the presence of up to $1 \mathrm{~mol} \mathrm{~L}^{-1}$ 
of $\mathrm{NaCl}^{9}$ ICP-MS operating parameters are summarized in Table S1 (ESI $\dagger)$.

A WTW $330 \mathrm{pH}$ meter (WTW GmbH, Weilheim, Germany) was employed to determine the $\mathrm{pH}$.

A Mettler AE 163 (Mettler Toledo, Zürich, Switzerland) analytical balance was used for weighing.

\subsection{Reagents and materials}

All solutions were made up using ultrapure $18.2 \mathrm{M} \Omega \mathrm{cm}$ water (MilliQ) obtained from a Direct-Q 5 Ultrapure water system (Millipore Watertown, MA, USA). Suprapur sodium hydroxide monohydrate $\left(\mathrm{NaOH} \cdot \mathrm{H}_{2} \mathrm{O}\right)$ and Suprapur sodium carbonate $\left(\mathrm{Na}_{2} \mathrm{CO}_{3}\right)$ from Merck (Darmstadt, Germany) were used for the preparation of alkaline buffer solutions $(2 \% \mathrm{NaOH}+3 \%$ sodium carbonate $\mathrm{Na}_{2} \mathrm{CO}_{3}$ ) and ultrapure hydrochloric acid $(\mathrm{HCl})$ to adjust the $\mathrm{pH}$ of standard solutions applied in speciation analysis. As a reducing agent, anhydrous sodium sulphite $\left(\mathrm{Na}_{2} \mathrm{SO}_{3}\right)$ from Acros Organics (Geel, Belgium) was used. Stock standard solutions of $\mathrm{Cr}$, As, V, Ge, Sc, In and Rh (1000 $\pm 2 \mathrm{mg}$ $\mathrm{L}^{-1}$ in $2-3 \% \mathrm{HNO}_{3}$ ) were purchased from Merck. Chromate was prepared from a stock solution of $\mathrm{K}_{2} \mathrm{CrO}_{4}$ in water (Merck), containing $1000 \pm 2 \mu \mathrm{g} \mathrm{mL}^{-1}$ of $\mathrm{CrO}_{4}{ }^{2-}$ and molybdate from a stock solution of $\left(\mathrm{NH}_{4}\right)_{6} \mathrm{Mo}_{7} \mathrm{O}_{24}$ in water (Merck), containing $1000 \pm 2 \mu \mathrm{g} \mathrm{mL} \mathrm{m}^{-1}$ of Mo. Arsenate and arsenite stock solutions $\left(1000 \pm 2 \mu \mathrm{g}\right.$ As $\left.\mathrm{mL}^{-1}\right)$ were made by dissolving $0.4170 \mathrm{~g}$ of $\mathrm{Na}_{2} \mathrm{HAsO}_{4} \cdot 7 \mathrm{H}_{2} \mathrm{O}$ salt (Sigma-Aldrich, St Louis, MO, USA) in $100 \mathrm{~mL}$ of water and by appropriate dilution of $0.05 \mathrm{~mol} \mathrm{~L}^{-1}$ $\mathrm{NaAsO}_{2}$ (Sigma-Aldrich) with water, respectively, while for the preparation of vanadate stock solution, $0.2296 \mathrm{~g}$ of $\mathrm{NH}_{4} \mathrm{VO}_{3}$ p.a. salt (Merck) was dissolved in $100 \mathrm{~mL}$ of alkaline buffer to obtain a solution containing $1000 \pm 2 \mu \mathrm{g} \mathrm{V} \mathrm{mL}{ }^{-1}$. Sodium chloride of suprapur quality (Merck) was used in HPLC separations.

\subsection{Preparation of working standard solutions}

To follow the behaviour of chromate, arsenate, molybdate and vanadate on a HPLC column with ICP-MS detection, working standard solutions were prepared daily by the appropriate dilution of stock standard solutions at $\mathrm{pH}$ of 5 (adjusted with $0.0006 \mathrm{~mol} \mathrm{~L}^{-1} \mathrm{HCl}$ ) and at $\mathrm{pH}$ of 12 (using buffer solution composed of $0.2 \% \mathrm{NaOH}+0.3 \% \mathrm{Na}_{2} \mathrm{CO}_{3}$ ). For examining the efficacy of the analytical procedure to separate species of individual elements in their highest and lower oxidation states, $\mathrm{Cr}(\mathrm{III})$ and As(III) standard solutions were used. For preparing Mo and $\mathrm{V}$ species in their lower oxidation states, $1 \mathrm{~mL}$ of $\mathrm{Na}_{2} \mathrm{SO}_{3}$ solution ( $0.004 \mathrm{~g} \mathrm{~mL}^{-1}$ and $0.002 \mathrm{~g} \mathrm{~L}^{-1}$, respectively) was added to molybdate and vanadate working standard solutions and the contents were diluted to $10 \mathrm{~mL}$.

\subsection{Preparation of building composites from fly ash, cement and electric arc furnace dust}

Building composites were prepared from fly ash and EAF dust obtained from the coal-fired power station Pljevlja and the steelmill Nikšić in Montenegro, and portland cement CEM II/B-M(SLL) $42.5 \mathrm{~N}$. They were composed of $99.5 \%$ mixture of fly ash (70\%) and cement (30\%) and $0.5 \%$ EAF dust, 99.5\% mixture of fly ash (80\%) and cement (20\%) and 0.5\% EAF dust, 100\% mixture of fly ash (70\%) and cement (30\%), and 98\% mixture of fly ash (80\%) and cement (20\%) and $2 \%$ EAF dust. The composite casts were cylinders, $7 \mathrm{~cm}$ in height and $5 \mathrm{~cm}$ in diameter, with a volume of approximately $0.137 \mathrm{~L}$. The composites were immersed into MilliQ water and leachates taken 1 day or 9 months after the start of the experiment.

\subsection{Speciation procedure}

The separation procedure that was originally developed and validated for speciation of $\mathrm{Cr}(\mathrm{vI})$ by HPLC-ICP-MS was applied. ${ }^{9}$ $0.2 \mathrm{~mL}$ of the sample was injected onto the column. To reduce the blank arising from the stainless steel needle, the sample was drawn with the syringe in the opposite direction through the plastic tube of the waste exit from the injector (reverse injection). ${ }^{9}$ Linear gradient elution from water to $0.7 \mathrm{M} \mathrm{NaCl}(0-$ $100 \%$ ) was applied for $10 \mathrm{~min}$ at a flow rate of $1.5 \mathrm{~mL} \mathrm{~min}{ }^{-1}$. The eluate from the column was connected on-line to the ICPMS. After separation, the column was regenerated with $2 \mathrm{~mol}$ $\mathrm{L}^{-1} \mathrm{NaCl}$ for $3 \mathrm{~min}$ and equilibrated with water for $7 \mathrm{~min}$. The eluate from the regeneration step was directed to waste through a software controlled six-port valve. The stability and robustness of the chromatographic column in the $\mathrm{pH}$ range 2 to 12 enabled analysis of acidic ( $\mathrm{pH} 5)$ and highly alkaline ( $\mathrm{pH} 12)$ samples. Cleaning of the Mono Q column was performed after each set of experiments when the $\mathrm{pH}$ of the samples investigated was changed. For cleaning, $0.5 \mathrm{~mL}$ of $1 \mathrm{~mol} \mathrm{~L}^{-1}$ sodium hydroxide was injected onto the column resin and the chromatographic procedure applied. The cleaning procedure was repeated twice. Before each new series of experiments, two blank samples were first injected. ${ }^{9}$

At a $\mathrm{pH}$ of 12 , the procedure enabled separation of chromate, arsenate, molybdate and vanadate in a single chromatographic run from 390 to $450 \mathrm{~s}, 230$ to $270 \mathrm{~s}, 340$ to $430 \mathrm{~s}$ and 270 to $380 \mathrm{~s}$, respectively. Separated elemental species were detected on-line by ICP-MS, recording Cr, As, Mo and V at $m / z$ 52, 75, 95 and 51, respectively. When $\mathrm{V}$ in the sample was present in significantly higher concentrations than $\mathrm{Cr}$, Mo, and As, its signal was recorded at $m / z 50$.

If not stated otherwise, all the analyses were done at least in two replicates.

\section{Results and discussion}

3.1. Separation of chromium, arsenic, molybdenum and vanadium species on the HPLC column followed by ICP-MS detection

Properties of elements, like toxicity towards living organisms, behaviour and fate in the environment, etc. depend primarily on the chemical forms in which they are present in a given environment. Cr, Mo and $\mathrm{V}$ are more toxic in their highest oxidation states (Cr(vi), Mo(vi) and $\mathrm{V}(\mathrm{v})$, respectively), while $\mathrm{As}(\mathrm{v})$ is less toxic than As(III). ${ }^{26-29}$ Oxoanions of $\mathrm{Cr}(\mathrm{VI}), \mathrm{As}(\mathrm{v}), \mathrm{Mo}(\mathrm{vI})$ and $\mathrm{V}(\mathrm{v})$ are highly mobile in the form of alkali chromates, arsenates, molybdates and vanadates and can be present in leachates from building composites of fly ash, cement and EAF dust. To reduce the time and cost of analysis, the applicability of the HPLC-ICP- 
MS procedure was investigated for the simultaneous speciation of chromate, arsenate, molybdate and vanadate in highly alkaline leachate samples. First, the behaviour of single elemental species in their highest and lower oxidation states was examined on an anion-exchange HPLC column applying the speciation procedure as described in Section 2.5. The study was performed using working standard solutions containing $20 \mathrm{ng}$ $\mathrm{mL}^{-1}$ of a particular elemental species, prepared at pH 5 and 12 (see Section 2.3). The results are presented in Fig. 1-4.

For the study of $\mathrm{Cr}$ speciation (Fig. 1), aqueous standard solutions of chromate and $\mathrm{Cr}$ (III)-nitrate were used. In aqueous solutions more acidic than $\mathrm{pH} 5, \mathrm{Cr}(\mathrm{III})$ exists mainly as the positively charged $\mathrm{Cr}\left(\mathrm{H}_{2} \mathrm{O}\right)_{6}{ }^{3+}$ complex, while $\mathrm{Cr}(\mathrm{vI})$ as the negatively charged $\mathrm{Cr}_{2} \mathrm{O}_{7}{ }^{2-}$ species. At $\mathrm{pH} 12, \mathrm{Cr}(\mathrm{III})$ is mainly present in the form of sparingly soluble $\mathrm{Cr}(\mathrm{OH})_{3}$, and to a smaller extent also as the soluble $\mathrm{Cr}(\mathrm{OH})_{4}{ }^{-}$complex, whereas $\mathrm{Cr}(\mathrm{vI})$ exists as the $\mathrm{CrO}_{4}{ }^{2-}$ species. ${ }^{30}$ Data from Fig. 1A show that $\mathrm{Cr}(\mathrm{III})$ at pH 5 is eluted with a solvent front, while $\mathrm{Cr}$ (VI) from 430 to $490 \mathrm{~s}$ (Fig. 1B). At pH 12, Cr(III) is mostly precipitated as $\mathrm{Cr}(\mathrm{OH})_{3}$, which is strongly adsorbed on the column resin, while a small peak that eluted from 220 to $240 \mathrm{~s}$ corresponds to the $\mathrm{Cr}(\mathrm{OH})_{4}{ }^{-}$complex (Fig. 1C). $\mathrm{Cr}(\mathrm{vI})$ is eluted from 390 to $450 \mathrm{~s}$ (Fig. 1D), and is separated from Cr(III) species. The small peak of the blank solution, which corresponds to $\mathrm{Cr}(\mathrm{vI})$ (Fig. 1C and D) arises from the alkaline buffer solution, in which $\mathrm{Cr}$ (III) and $\mathrm{Cr}(\mathrm{vI})$ standards were prepared at $\mathrm{pH} 12$.

For the investigation of As speciation (Fig. 2), aqueous standard solutions of arsenite (As(III)) and arsenate (As(v)) were used. At a pH of 5, $\mathrm{As}(\mathrm{III})$ is present as $\mathrm{H}_{3} \mathrm{AsO}_{3}$ and $\mathrm{As}(\mathrm{v})$ as $\mathrm{H}_{2} \mathrm{AsO}_{4}{ }^{-}$species. ${ }^{31}$ The data in Fig. $2 \mathrm{~A}$ and $\mathrm{B}$ indicate that in acidic solutions As(III) and As(v) species are well separated. At pH $12 \mathrm{As}(\mathrm{III})$ exists mainly as $\mathrm{As}(\mathrm{OH})_{3},{ }^{32}$ and to a smaller extent as soluble $\mathrm{HAsO}_{3}{ }^{2-}$ and $\mathrm{AsO}^{3-}$ species. ${ }^{31}$ At highly alkaline pHs, the only $\mathrm{As}(\mathrm{v})$ species is $\mathrm{AsO}_{4}{ }^{3-}{ }^{31}$ The data in Fig. $2 \mathrm{C}$ show that
$\mathrm{As}(\mathrm{OH})_{3}$ is strongly adsorbed on the column resin, while $\mathrm{HAsO}_{3}{ }^{2-}$ and $\mathrm{AsO}^{3-} \mathrm{As}(\mathrm{III})$ species are eluted as two small peaks from 50 to 150 s. From Fig. 2D it can be seen that As(v) species is eluted as a sharp peak from 230 to $270 \mathrm{~s}$ and is separated from As(III).

Investigation of Mo speciation at $\mathrm{pH} 5$ and 12 is presented in Fig. 3. From acidic to alkaline pHs $\mathrm{Mo}(\mathrm{vI})$ prevails as $\mathrm{MoO}_{4}{ }^{2-}$ species. ${ }^{33}$ In lower oxidation states, Mo species are in aqueous solutions and stable only at acidic pHs, in the form of the positively charged trivalent $\mathrm{Mo}\left(\mathrm{H}_{2} \mathrm{O}\right)_{6}{ }^{3+}$, tetravalent $\mathrm{Mo}_{3} \mathrm{O}_{4}{ }^{4+}$ and pentavalent $\mathrm{Mo}_{2} \mathrm{O}_{4}{ }^{2+}$ complexes. ${ }^{34,35}$ The aqua monomeric trivalent, tetravalent and pentavalent Mo species tend to polymerise, forming di- or trinuclear oxo Mo species. ${ }^{35}$ In the study of $\mathrm{Mo}(\mathrm{vI})$ speciation, molybdate standard solution was used. Mo compounds in lower oxidation states are not soluble in water and can be dissolved by alkaline digestion, which induces oxidation to $\mathrm{Mo}(\mathrm{vI})$, and thus changes the speciation. To prepare Mo species in the lower oxidation states, $\mathrm{Na}_{2} \mathrm{SO}_{3}$ was added as a reducing agent to a standard solution of molybdate and the $\mathrm{pH}$ adjusted to 5 and 12 . This reducing agent was chosen since it is present in the samples of alkaline leachates from flay ash, EAF dust and cement. ${ }^{20}$ The results of these experiments are presented in Fig. 3. As can be seen from Fig. 3A, at $\mathrm{pH} 5$ the monomeric Mo species formed after the reduction of $\mathrm{Mo}(\mathrm{vI})$ are eluted with the solvent front, while polymeric Mo(v), Mo(Iv) and Mo(III) species are adsorbed on the column resin. Mo(vI) is eluted from 330 to $420 \mathrm{~s}$ (Fig. 3B) and is separated from species in lower oxidation states. At $\mathrm{pH} 12$, the separated $\mathrm{Mo}(\mathrm{vI})$ species are eluted from 340 to $430 \mathrm{~s}$ (Fig. 3C and D). The addition of the reducing agent $\left(0.0004 \mathrm{~g} \mathrm{~mL}^{-1} \mathrm{Na}_{2} \mathrm{SO}_{3}\right)$ to $\mathrm{Mo}(\mathrm{vI})$ solution resulted in $20 \%$ decrease of the Mo chromatographic signal. Reduced Mo species were adsorbed on the column resin and were separated from $\mathrm{Mo}(\mathrm{vI})$. A peak of the blank solution at $\mathrm{pH}$ 12 , which represents about $12 \%$ of the analytical signal of
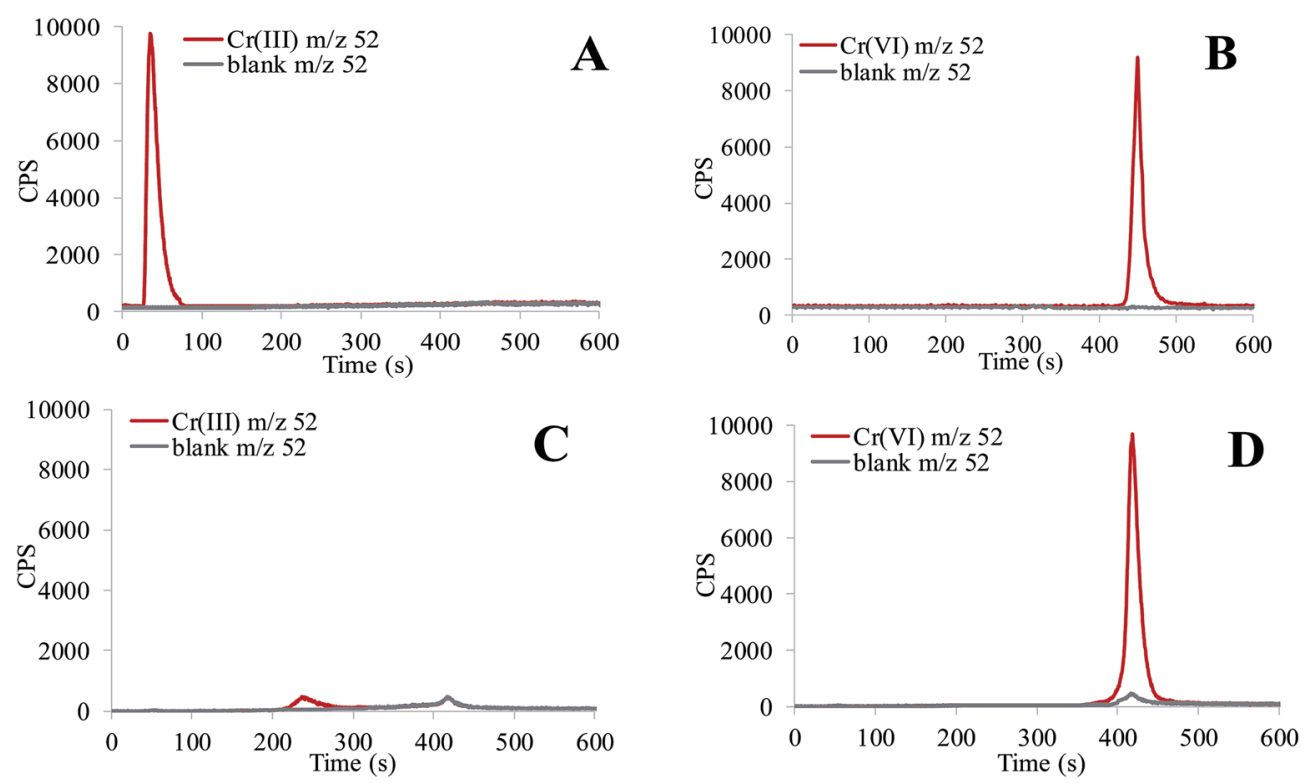

Fig. 1 Separation of (A) $\mathrm{Cr}\left(\right.$ III) solution ( $\mathrm{pH}$ 5), (B) $\mathrm{Cr}(\mathrm{vI})$ solution ( $\mathrm{pH}$ 5), (C) $\mathrm{Cr}(\mathrm{II})$ solution in $0.2 \% \mathrm{NaOH}+0.3 \% \mathrm{Na}_{2} \mathrm{CO}_{3}$ buffer (pH 12) and (D) Cr(vı) solution in $0.2 \% \mathrm{NaOH}+0.3 \% \mathrm{Na}_{2} \mathrm{CO}_{3}$ buffer ( $\left.\mathrm{pH} 12\right)$ applying the HPLC-ICP-MS procedure $\left(20 \mathrm{ng} \mathrm{mL}^{-1}\right.$ of $\mathrm{Cr}$ ). 

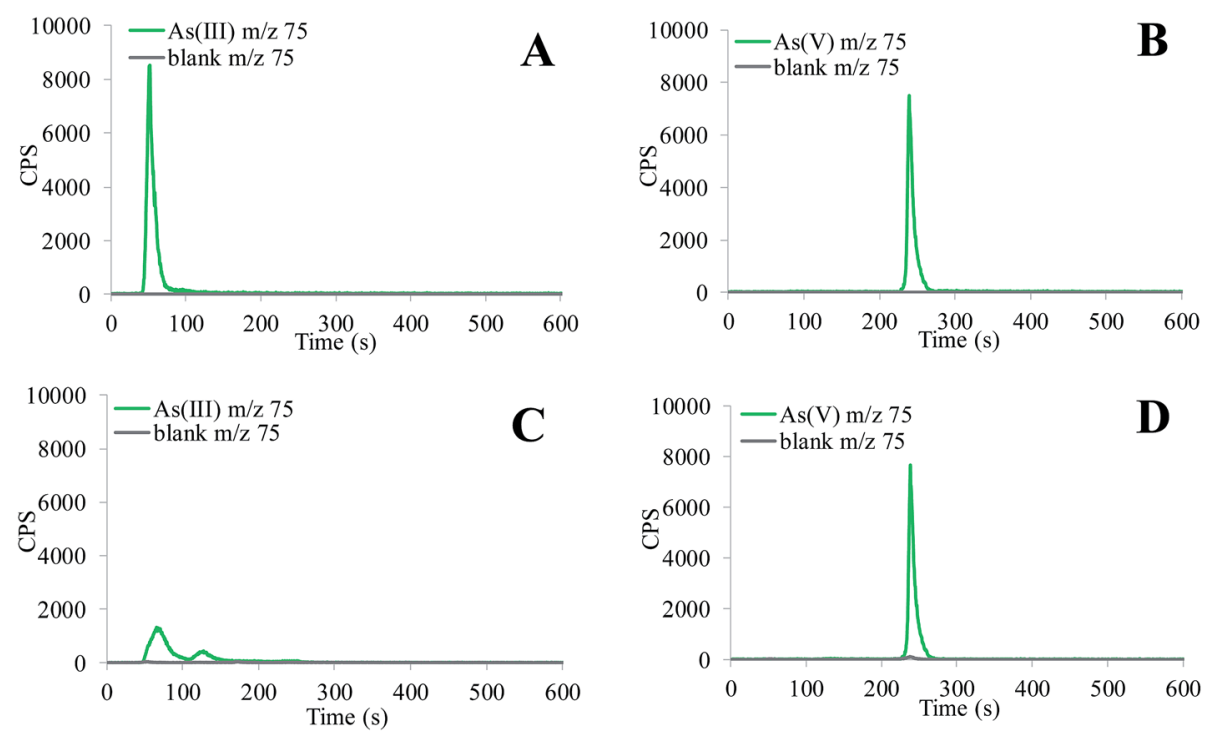

Fig. 2 Separation of (A) As(III) solution ( $\mathrm{pH} 5)$, (B) As(v) solution (pH 5), (C) As(III) solution in $0.2 \% \mathrm{NaOH}+0.3 \% \mathrm{Na}_{2} \mathrm{CO}_{3}$ buffer (pH 12$)$ and (D) As(v) solution in $0.2 \% \mathrm{NaOH}+0.3 \% \mathrm{Na}_{2} \mathrm{CO}_{3}$ buffer $(\mathrm{pH} 12)$ applying the HPLC-ICP-MS procedure (20 $\mathrm{ng} \mathrm{mL}^{-1}$ of As).

Mo(vi), arises mainly from the metallic parts of the HPLC and injector and to a smaller extent also from the alkaline extract.

The study of $\mathrm{V}$ speciation at $\mathrm{pH} 5$ and 12 is presented in Fig. 4. In aqueous solutions with acidic $\mathrm{pHs}, \mathrm{H}_{2} \mathrm{VO}_{4}{ }^{-}$is a prevailing pentavalent monomeric $\mathrm{V}$ species, ${ }^{36-38}$ which co-exists with the polyoxovanadate $\mathrm{V}_{4} \mathrm{O}_{12}{ }^{4-}$ and $\mathrm{HV}_{10} \mathrm{O}_{28}{ }^{5-}$ ions. The latter decavanadate anion is the predominant polymeric $\mathrm{V}$ species in the $\mathrm{pH}$ range between 3 and $6 .^{38,39}$ At $\mathrm{pH} 12, \mathrm{VO}_{4}{ }^{3-}$ species prevails. ${ }^{36-38}$ The main $\mathrm{V}$ species in lower oxidation states in aqueous solutions are tetravalent $\mathrm{VOOH}^{+}$and $\mathrm{VO}^{2+}$, and trivalent $\mathrm{V}\left(\mathrm{H}_{2} \mathrm{O}\right)_{6}{ }^{3+}$ aqua complex and $\mathrm{VOH}^{+}$species, which are stable at acidic pHs. ${ }^{36,37}$ Since tetravalent and trivalent $\mathrm{V}$ compounds are sparingly soluble in water, $\mathrm{Na}_{2} \mathrm{SO}_{3}$ $\left(0.0002 \mathrm{~g} \mathrm{~mL}^{-1}\right)$ was added as a reducing agent to a standard solution of vanadate to prepare the $\mathrm{V}$ species in the lower oxidation states. Then the $\mathrm{pH}$ was adjusted to 5 and 12. From data presented in Fig. $4 \mathrm{~A}$ and $\mathrm{B}$ it can be seen that at $\mathrm{pH}, \mathrm{V}(\mathrm{v})$ is separated from $\mathrm{V}$ species in the lower oxidation states. The positively charged $\mathrm{V}$ complexes formed after the reduction of $\mathrm{V}(\mathrm{v})$ are eluted with the solvent front, whereas negatively charged pentavalent polyoxovanadate complexes are eluted as a broad peak from 300 to $600 \mathrm{~s}$. At $\mathrm{pH} 12$, the pentavalent $\mathrm{VO}_{4}{ }^{3-}$ species is eluted from 270 to $380 \mathrm{~s}$ (Fig. 4D). The addition of a reducing agent to $\mathrm{V}(\mathrm{v})$ solution resulted in about $50 \%$ decrease
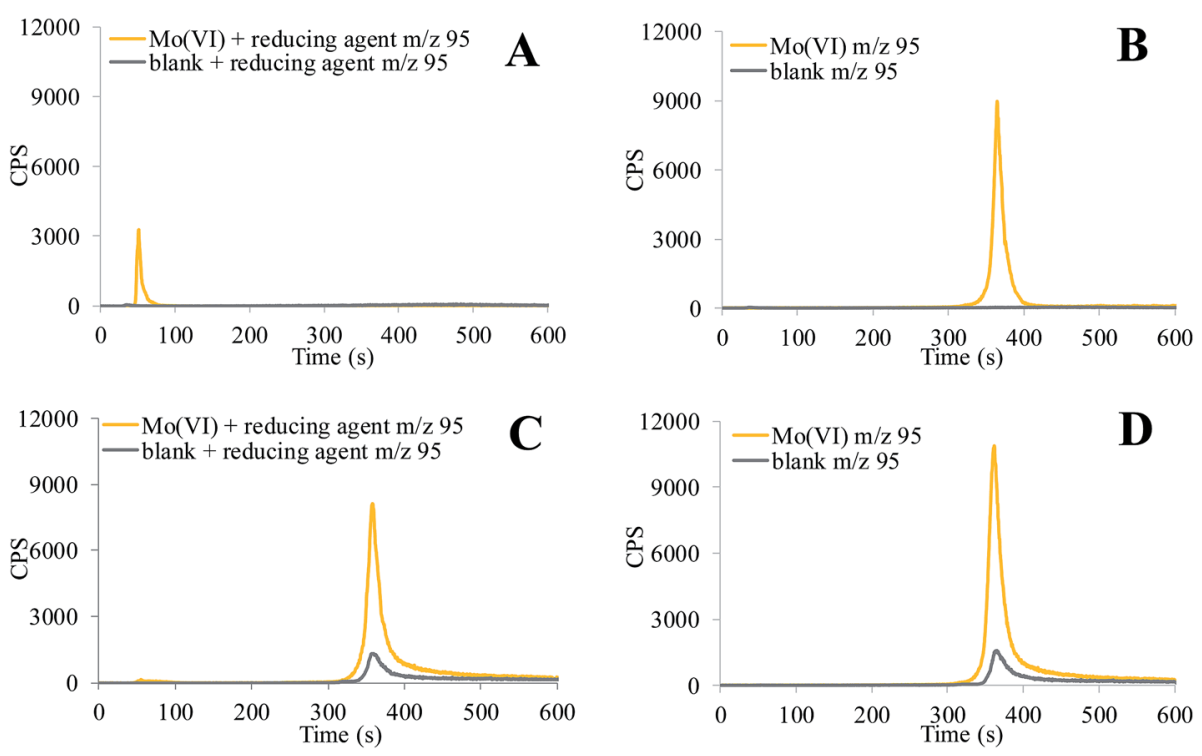

Fig. 3 Separation of (A) Mo(vI) solution (pH 5) in the presence of a reducing agent $0.0002 \mathrm{~g} \mathrm{~L}^{-1} \mathrm{Na}_{2} \mathrm{SO}_{3}$, (B) Mo(vI) solution (pH 5), (C) Mo(vI) solution in $0.2 \% \mathrm{NaOH}+0.3 \% \mathrm{Na}_{2} \mathrm{CO}_{3}$ buffer $(\mathrm{pH} 12)$ in the presence of a reducing agent $0.0004 \mathrm{~g} \mathrm{~mL}^{-1} \mathrm{Na}_{2} \mathrm{SO}_{3}$ and (D) Mo(v) solution in $0.2 \%$ $\mathrm{NaOH}+0.3 \% \mathrm{Na}_{2} \mathrm{CO}_{3}$ buffer ( $\mathrm{pH}$ 12) applying the HPLC-ICP-MS procedure (20 $\mathrm{ng} \mathrm{mL}^{-1}$ of Mo). 

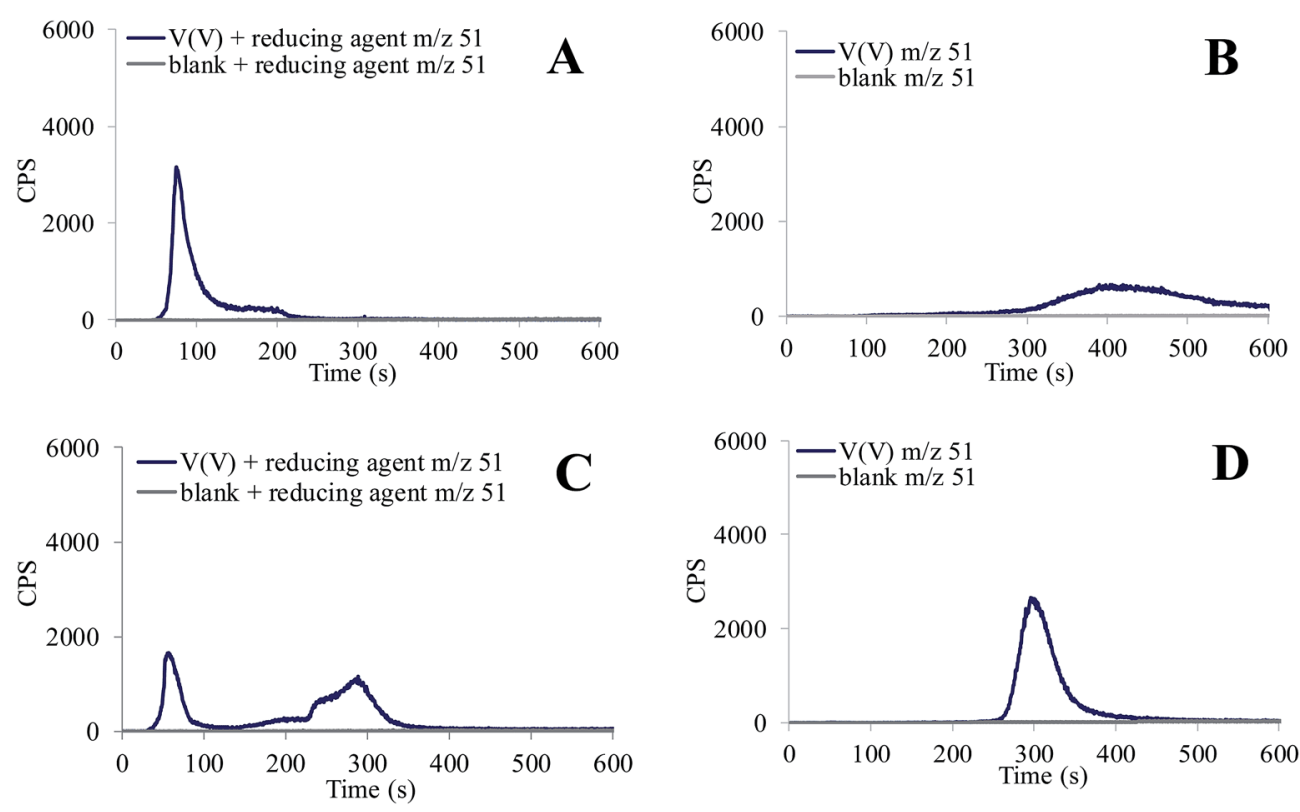

Fig. 4 Separation of (A) V(v) solution ( $\mathrm{pH} 5)$ in the presence of a reducing agent $0.0002 \mathrm{~g} \mathrm{~L}^{-1} \mathrm{Na}_{2} \mathrm{SO}_{3}$, (B) V(v) solution ( $\left.\mathrm{pH} 5\right)$, (C) V(v) solution in $0.2 \% \mathrm{NaOH}+0.3 \% \mathrm{Na}_{2} \mathrm{CO}_{3}$ buffer $(\mathrm{pH} 12)$ in the presence of a reducing agent $0.0002 \mathrm{~g} \mathrm{~mL}^{-1} \mathrm{Na}_{2} \mathrm{SO}_{3}$ and (D) $\mathrm{V}(\mathrm{V})$ solution in $0.2 \% \mathrm{NaOH}+0.3 \%$ $\mathrm{Na}_{2} \mathrm{CO}_{3}$ buffer ( $\mathrm{pH} 12$ ) applying the HPLC-ICP-MS procedure (20 $\mathrm{ng} \mathrm{mL}^{-1}$ of $\mathrm{V}$ ).

of the $\mathrm{V}(\mathrm{v})$ chromatographic signal, while $\mathrm{V}$ species in the lower oxidation states are eluted with the solvent front (Fig. 4C).

From the data in Fig. 1-4 it can be concluded that under the chromatographic conditions applied, speciation of chromate, arsenate, molybdate and vanadate is possible at highly alkaline pHs.

3.2. Simultaneous speciation of chromium, arsenic, molybdenum and vanadium species by the HPLC-ICP-MS method

To demonstrate the capability of the HPLC-ICP-MS analytical procedure for simultaneous speciation analysis, a multiple working standard solution containing $20 \mathrm{ng} \mathrm{mL} \mathrm{mL}^{-1}$ of chromate, arsenate, molybdate and vanadate was prepared in alkaline buffer ( $\mathrm{pH}$ 12). Separated elemental species of $\mathrm{Cr}$, As, Mo and V were simultaneously detected by ICP-MS recording $m / z 52,75$, 95 and 51, respectively. A typical chromatogram is presented in

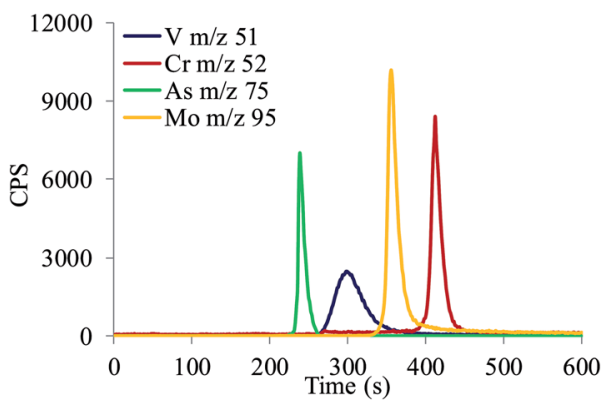

Fig. 5 Simultaneous separation of chromate, arsenate, molybdate and vanadate in $0.2 \% \mathrm{NaOH}+0.3 \% \mathrm{Na}_{2} \mathrm{CO}_{3}$ buffer $(\mathrm{pH} 12)$ applying the HPLC-ICP-MS procedure (20 $\mathrm{ng} \mathrm{mL}^{-1}$ of $\mathrm{Cr}$, As, Mo and V).
Fig. 5. As evident, at pH 12, chromate, arsenate, molybdate and vanadate were eluted from 390 to $450 \mathrm{~s}, 230$ to $270 \mathrm{~s}, 340$ to $430 \mathrm{~s}$ and 270 to $380 \mathrm{~s}$, respectively. Different elution times are related to different affinities of species for their retention on the anionexchange resin. Since elution profiles were recorded at different $\mathrm{m} / \mathrm{z}$ by ICP-MS, simultaneous speciation analysis of chromate, arsenate, molybdate and vanadate can be performed in a single chromatographic run, although the molybdate peak partially overlapped vanadate and chromate peaks.

If samples contain significantly higher concentrations of vanadate compared to those of chromate, arsenate and molybdate, detection of $\mathrm{V}$ species is possible even at its low abundance $(0.25 \%){ }^{50} \mathrm{~V}$ isotope. ${ }^{24}$ Since ${ }^{50} \mathrm{~V}$ isotope shares the same mass with ${ }^{50} \mathrm{Cr}$ isotope (abundance $4.345 \%$ ), ${ }^{24}$ simultaneous speciation analysis of $\mathrm{V}$ at $m / z 50$ is possible only if $\mathrm{V}$ and $\mathrm{Cr}$ species are selectively separated to avoid isobaric interferences in ICP-MS measurements. An example of simultaneous separation of chromate and vanadate at $m / z 50$ in alkaline ( $\mathrm{pH} 12)$ solution containing $100 \mathrm{ng} \mathrm{mL} \mathrm{L}^{-1}$ of $\mathrm{Cr}$ and $1000 \mathrm{ng} \mathrm{mL} \mathrm{m}^{-1}$ of $\mathrm{V}$ is presented in Fig. 6 . As can be seen, chromate and vanadate are well separated and can be simultaneously recorded at $\mathrm{m} / \mathrm{z} 50$.

\subsection{Figures of merit of the HPLC-ICP-MS analytical method used for simultaneous speciation of chromate, arsenate, molybdate and vanadate in alkaline samples}

3.3.1. Column recoveries. Possible interactions between the column resin and chromate, arsenate, molybdate and vanadate were checked by calculating column recoveries. For this purpose, single standard solutions of chromate, arsenate, molybdate and vanadate (20 $\mathrm{ng} \mathrm{mL}^{-1}$ as the element) were prepared in alkaline buffer $(\mathrm{pH} 12)$ and injected onto the column. Fractions eluted under the elution time typical for 


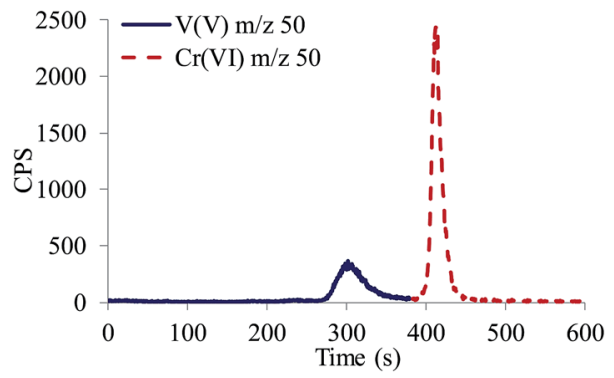

Fig. 6 Simultaneous separation of chromate and vanadate in $0.2 \%$ $\mathrm{NaOH}+0.3 \% \mathrm{Na}_{2} \mathrm{CO}_{3}$ buffer $(\mathrm{pH} 12)$ applying the HPLC-ICP-MS procedure (100 $\mathrm{ng} \mathrm{mL}^{-1}$ of $\mathrm{Cr}$ and $1000 \mathrm{ng} \mathrm{mL}^{-1}$ of V). Chromatograms were recorded at $m / z 50$.

a particular species investigated were collected and the total elemental concentration was determined "off line" by ICP-MS. Column recoveries were calculated as the ratio between those concentrations of elemental species eluted and injected. The results are presented in Table 1.

As can be seen, for all the elemental species investigated column recoveries ranged between 99 and 105\%, indicating that chromate, arsenate, molybdate and vanadate are quantitatively eluted and did not interact with the column resin.

3.3.2 Repeatability of measurements. The repeatability of measurements was tested for six consecutive simultaneous speciation analysis of a standard solution of chromate, arsenate, molybdate and vanadate, containing $20 \mathrm{ng} \mathrm{mL} \mathrm{m}^{-1}$ of $\mathrm{Cr}$, As, $\mathrm{Mo}$ and $\mathrm{V}$ in alkaline buffer solution ( $\mathrm{pH} 12)$. From results presented in Table 2 it is evident that the repeatability of measurements for the elemental species studied was found to be better than $\pm 3 \%$.

Table 1 Column recoveries for separation of single elemental species of chromate, arsenate, molybdate and vanadate in $0.2 \% \mathrm{NaOH}+0.3 \%$ $\mathrm{Na}_{2} \mathrm{CO}_{3}$ buffer ( $\mathrm{pH}$ 12) applying the HPLC-ICP-MS procedure. Results represent the mean value of three replicate determinations of the selected element with the standard deviation of the measurements

\begin{tabular}{llll}
\hline & $\begin{array}{l}\text { Concentration of } \\
\text { element added } \\
\left(\mathrm{ng} \mathrm{mL} \mathrm{mL}^{-1}\right)\end{array}$ & $\begin{array}{l}\text { Concentration of } \\
\text { element found } \\
\left(\mathrm{ng} \mathrm{mL}^{-1}\right)\end{array}$ & $\begin{array}{l}\text { Recovery } \\
(\%)\end{array}$ \\
\hline $\mathrm{Cr}(\mathrm{vI}) m / z 52$ & $20.0 \pm 0.2$ & $19.8 \pm 0.2$ & 99 \\
$\mathrm{As}(\mathrm{v}) m / z 75$ & $20.0 \pm 0.2$ & $19.8 \pm 0.2$ & 99 \\
$\mathrm{Mo}(\mathrm{vI}) m / z 95$ & $20.0 \pm 0.2$ & $21.0 \pm 0.2$ & 105 \\
$\mathrm{~V}(\mathrm{v}) m / z 51$ & $20.0 \pm 0.2$ & $20.0 \pm 0.2$ & 100
\end{tabular}

Table 2 Repeatability of measurement tested for six consecutive speciation analysis of a standard solution of chromate, arsenate, molybdate and vanadate, containing $20 \mathrm{ng} \mathrm{mL}^{-1}$ of $\mathrm{Cr}$, As, Mo and V

\begin{tabular}{|c|c|c|c|c|c|c|c|c|}
\hline Species & 1 & 2 & 3 & 4 & 5 & 6 & Average & $\mathrm{RSD} \%$ \\
\hline $\operatorname{As}(\mathrm{v}) m / z 75$ & 13138 & 12959 & 13359 & 13483 & 13101 & 13408 & 13241 & 1.6 \\
\hline $\operatorname{Mo}(\mathrm{vI}) m / z 95$ & 133624 & 134412 & 134320 & 136870 & 134482 & 131434 & 134190 & 1.3 \\
\hline $\mathrm{V}(\mathrm{v}) m / z 51$ & 84034 & 82286 & 84585 & 82317 & 81145 & 85777 & 83357 & 2.1 \\
\hline
\end{tabular}

3.3.3. Limits of detection. Limits of detection (LODs) and limits of quantification (LOQs) for the determination of chromate, molybdate, arsenate and vanadate by HPLC-ICP-MS were calculated as the concentration that provides a signal (peak area) equal to $3 s$ and $10 s$, respectively, of the blank sample in the chromatogram. To calculate LODs and LOQs, 8 blank samples of the alkaline buffer solution $(0.2 \% \mathrm{NaOH}+0.3 \%$ $\mathrm{Na}_{2} \mathrm{CO}_{3}$ ) were injected and $\mathrm{Cr}$, As, Mo and V recorded at $m / z 52$, 75, 95 and 51, respectively. By the use of ICP-MS operating parameters summarized in Table S1, $\dagger$ the LODs and LOQs for chromate $(\mathrm{m} / \mathrm{z} 52)$ were 0.2 and $0.67 \mathrm{ng} \mathrm{Cr} \mathrm{mL}{ }^{-1}$, arsenate $(\mathrm{m} / \mathrm{z}$ 75) 0.4 and $1.33 \mathrm{ng}$ As $\mathrm{mL}^{-1}$, molybdate $(\mathrm{m} / \mathrm{z} 95) 1$ and $3.33 \mathrm{ng}$ Mo $\mathrm{mL}^{-1}$, vanadate $\left(\mathrm{m} / z\right.$ 51) 2 and $6.66 \mathrm{ng} \mathrm{V} \mathrm{mL}^{-1}$ and vanadate $(\mathrm{m} / \mathrm{z} 50) 100$ and $333 \mathrm{ng} \mathrm{V} \mathrm{mL}{ }^{-1}$, respectively. The method was proved to be of adequate sensitivity for the simultaneous speciation analysis of chromate, arsenate, molybdate and vanadate in leachates from building composites.

3.3.4. Linearity. The linearity of measurement for chromate $(\mathrm{m} / \mathrm{z} 52)$, arsenate $(\mathrm{m} / \mathrm{z} 75)$, molybdate $(\mathrm{m} / \mathrm{z} 95)$ and vanadate $(\mathrm{m} /$ $z$ 51) by the HPLC-ICP-MS was obtained over the concentration range from LOQ to $1500 \mathrm{ng} \mathrm{mL} \mathrm{m}^{-1}$, while for vanadate recorded

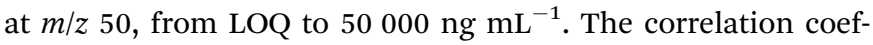
ficients were better than 0.998 for all the elements investigated.

3.3.5. Accuracy check. As there is no certified reference material for the simultaneous determination of chromate, arsenate, molybdate and vanadate available, the accuracy of the analytical procedure was checked by the spike recovery test. For this purpose, multiple standard solution of chromate, arsenate, molybdate and vanadate (pH 12), containing $50 \mathrm{ng} \mathrm{mL} \mathrm{m}^{-1}$ of $\mathrm{Cr}, 100 \mathrm{ng} \mathrm{mL} \mathrm{m}^{-1}$ of As,

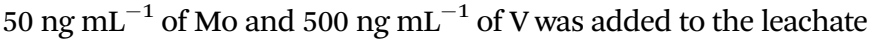
sample, composed of $99.5 \%$ mixture ( $70 \%$ fly ash $+30 \%$ cement) and $0.5 \%$ EAF dust, one day after immersion into MilliQ water. The sample was diluted 1:2 with alkaline buffer before analysis. The recoveries were calculated as a ratio between found and added element concentration. The results are presented in Table S2. $\dagger$

Data from Table S2† indicate that recoveries for chromate, arsenate, molybdate and vanadate of the spiked leachate sample lay between 98 and 102\%, which confirmed the accuracy of the analytical procedure.

\subsection{Simultaneous speciation analysis of chromate, arsenate, molybdate and vanadate in leachates from building composites by HPLC-ICP-MS at different concentration levels of vanadate}

The analytical procedure developed for the simultaneous speciation analysis of chromate, arsenate, molybdate and 
vanadate was applied to the analysis of alkaline leachates from building composites. In this experiment, different building composites from fly ash, EAF dust and cement were prepared and immersed into MilliQ water for two different times (1 day or 9 months). Due to the presence of soluble $\mathrm{Ca}(\mathrm{OH})_{2}$ and $\mathrm{CaCO}_{3}$ arising from the building composites, the $\mathrm{pH}$ values of the leachates were highly alkaline. ${ }^{20}$ In samples immersed for 1 day into MilliQ water the $\mathrm{pH}$ was 11, while in those immersed for 9 months, it was 13 . To perform speciation analysis within the linear concentration range, leachate samples obtained 1 day after immersion into MilliQ water were diluted $1: 2$ with alkaline buffer. Sample aliquots were injected onto the column and the simultaneous speciation analysis performed following the procedure described in Section 2.5. In samples immersed into MilliQ water for 9 months, concentrations of vanadate were significantly higher than those of chromate, arsenate and molybdate, so V detection was followed at $\mathrm{m} / \mathrm{z} 50$. The total concentrations of elements and elemental species in leachates are presented in Table 3, while their corresponding chromatograms in Fig. 7. As can be seen from the data of Table 3, sulphites and other reducing agents originating from building composites $^{\mathbf{2 0}}$ triggered the reduction of chromate, arsenate, molybdate and vanadate. The $\operatorname{Cr}(\mathrm{vI}), \operatorname{As}(\mathrm{v}), \operatorname{Mo}(\mathrm{vI})$ and $\mathrm{V}(\mathrm{v})$ concentrations represented about $40-70 \%$ of their total elemental content. Data from Fig. 7 demonstrate that the HPLCICP-MS analytical procedure developed is applicable for the simultaneous speciation analysis of chromate, arsenate, molybdate and vanadate in highly alkaline leachate samples. Selective separation of chromate from vanadate and the possibility to detect the eluted V species by ICP-MS at the low

Table 3 Total concentrations of $\mathrm{Cr}$, As, Mo and V determined by ICP-MS and concentrations of chromate, arsenate, molybdate and vanadate in leachates from building composites determined by HPLC-ICP-MS. (A1-A3) Leachates 1 day after immersion and (B1-B3) leachates 9 months after immersion into MilliQ water. Results represent the mean value of three replicate determinations of the selected element or elemental oxoanion species. The standard deviation of the measurements by ICP-MS is better than $1 \%$ and that of the HPLC-ICP-MS is better than $3 \%$

\begin{tabular}{|c|c|c|c|c|c|c|}
\hline Sample/element & Concentration & $\begin{array}{l}\text { Cr } m / z \\
52\left(\mathrm{ng} \mathrm{mL}{ }^{-1}\right)\end{array}$ & $\begin{array}{l}\text { As } m / z \\
75\left(\mathrm{ng} \mathrm{mL}^{-1}\right)\end{array}$ & $\begin{array}{l}\text { Mo } m / z \\
95\left(\mathrm{ng} \mathrm{mL}{ }^{-1}\right)\end{array}$ & $\begin{array}{l}\mathrm{V} \mathrm{m} / z \\
50\left(\mathrm{ng} \mathrm{mL}{ }^{-1}\right)\end{array}$ & $\begin{array}{l}\mathrm{V} m / z \\
51\left(\mathrm{ng} \mathrm{mL}^{-1}\right)\end{array}$ \\
\hline A1 & Total & 65 & 220 & 130 & - & 1635 \\
\hline $99.5 \%(70 \%$ fly ash $+30 \%$ cement $)+0.5 \%$ EAF dust & Oxoanion & 47 & 173 & 80 & - & 1120 \\
\hline $\mathrm{A} 2$ & Total & 49 & 230 & 97 & - & 1570 \\
\hline $99.5 \%(80 \%$ fly ash $+20 \%$ cement $)+0.5 \%$ EAF dust & Oxoanion & 28 & 139 & 40 & - & 795 \\
\hline A3 & Total & 60 & 193 & 132 & - & 1477 \\
\hline $100 \%(80 \%$ fly ash $+20 \%$ cement $)+0 \%$ EAF dust & Oxoanion & 37 & 140 & 68 & - & 900 \\
\hline B1 & Total & 82 & 2030 & 820 & - & 9080 \\
\hline $98 \%(80 \%$ fly ash $+20 \%$ cement $)+2 \%$ EAF dust & Oxoanion & 42 & 1085 & 338 & 4445 & - \\
\hline B2 & Total & 85 & 2080 & 830 & - & 7110 \\
\hline $98 \%(80 \%$ fly ash $+20 \%$ cement $)+2 \%$ EAF dust & Oxoanion & 39 & 1130 & 325 & 4500 & - \\
\hline B3 & Total & 86 & 2090 & 840 & - & 9970 \\
\hline $98 \%(80 \%$ fly ash $+20 \%$ cement $)+2 \%$ EAF dust & Oxoanion & 44 & 1265 & 378 & 5290 & - \\
\hline
\end{tabular}
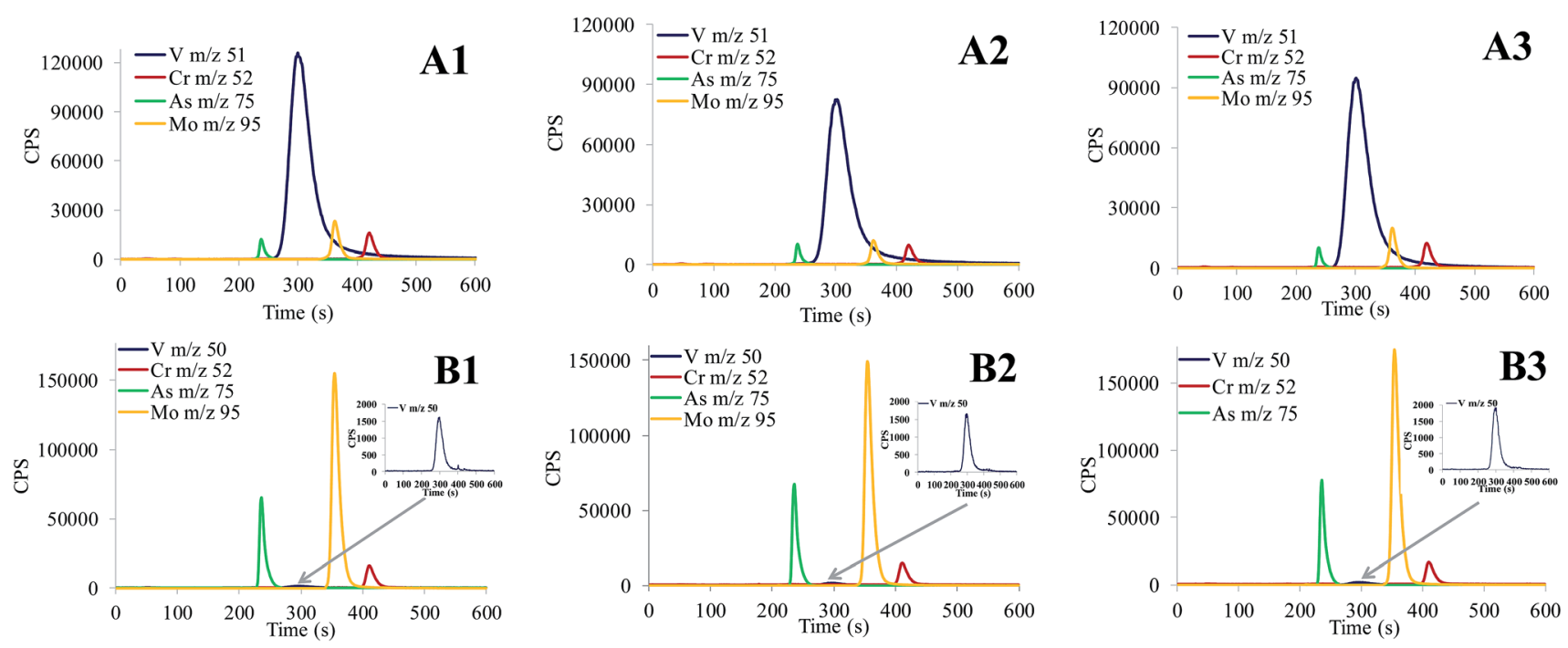

Fig. 7 Simultaneous separation of chromate, arsenate, molybdate and vanadate in leachates from building composites determined by HPLCICP-MS. (A1-A3) Leachate samples 1 day after immersion (samples diluted $1: 2$ with alkaline buffer) and (B1-B3) leachate samples 9 months after immersion into MilliQ water. Compositions of building composites are provided in Table 3. 
abundance ${ }^{50} \mathrm{~V}$ isotope extend its applicability for simultaneous speciation analysis to real world samples with significantly higher vanadate concentrations than chromate, arsenate and molybdate. The developed simultaneous speciation HPLC-ICPMS procedure also appreciably reduces the time and the cost of analysis.

\section{Conclusions}

A novel analytical procedure for the simultaneous speciation analysis of chromate, arsenate, molybdate and vanadate by anion-exchange HPLC-ICP-MS is reported. In multiple standard solutions prepared at $\mathrm{pH} 12$, the separated $\mathrm{Cr}$, As, Mo and V species were quantitatively eluted from the column resin and detected on-line by ICP-MS, recording $m / z 52,75,95$ and 51, respectively. Under the chromatographic conditions applied, selective separation of $\mathrm{Cr}$ and $\mathrm{V}$ species was achieved. This enabled us to measure the eluted $\mathrm{V}$ species at the low abundance $(0.25 \%){ }^{50} \mathrm{~V}$ isotope, which is also the mass of ${ }^{50} \mathrm{Cr}$ isotope (abundance $4.345 \%$ ). Using ${ }^{50} \mathrm{~V}$ isotope in ICP-MS detection, simultaneous speciation analysis was possible in highly alkaline leachates of building composites containing significantly higher concentrations of vanadate than chromate, arsenate and molybdate. The developed analytical method is reliable, accurate (spike recoveries between 98 and 102\%), repeatable (RSD $< \pm 3.0 \%$ ) and fast (chromatographic separation in $10 \mathrm{~min}$ ). To the best of our knowledge, this is the first report on simultaneous HPLC-ICP-MS speciation analysis of chromate, arsenate, molybdate and vanadate in highly alkaline samples. The possibility of the use of ${ }^{51} \mathrm{~V}$ and ${ }^{50} \mathrm{~V}$ isotopes in ICP-MS detection extends the applicability of the method to simultaneous speciation analysis in samples with wide concentration ranges of vanadate.

\section{Conflicts of interest}

There are no conflicts to declare.

\section{Acknowledgements}

This work was supported by the Ministry of Higher Education, Science and Technology of the Republic of Slovenia (Programme group P1-0143) and the MASSTWIN project that has received funding from the European Union's Horizon 2020 research and innovation programme under grant agreement no. 692241.

\section{References}

1 R. Clough, C. F. Harrington, S. J. Hill, Y. Madrid and J. F. Tyson, Atomic Spectrometry Update: Review of Advances in Elemental Speciation, J. Anal. At. Spectrom., 2016, 31, 1330-1373.

2 O. T. Butler, W. Cairns, J. M. Cook and C. M. Davidson, Atomic spectrometry update. Environmental analysis, $J$. Anal. At. Spectrom., 2011, 26, 250-286.
3 A. Taylor, N. Barlow, M. P. Day, S. Hill, M. Patriarca and M. White, Atomic spectrometry update: review of advances in the analysis of clinical and biological materials, foods and beverages, J. Anal. At. Spectrom., 2016, 31, 554-596.

4 Y. Morita, T. Kobayash, T. Kuroiwa and T. Narukawa, Study on simultaneous speciation of arsenic and antimony by HPLC-ICP-MS, Talanta, 2007, 73, 81-86.

5 A. J. Bednar, J. E. Mirecki, L. S. Inouye, L. E. Winfield, S. L. Larson and D. B. Ringelberg, The determination of tungsten, molybdenum, and phosphorus oxyanions by high performance liquid chromatography inductively coupled plasma mass spectrometry, Talanta, 2007, 27, 1828-1832.

6 R. E. Wolf, S. A. Morman, P. L. Hageman, T. M. Hoefen and G. S. Plumlee, Simultaneous speciation of arsenic, selenium, and chromium: species stability, sample preservation, and analysis of ash and soil leachates, Anal. Bioanal. Chem., 2011, 401, 2733-2745.

7 S. Szopa and R. Michalski, Simultaneous determination of inorganic forms of arsenic, antimony, and thallium by HPLC-ICP-MS, Spectroscopy, 2015, vol. 30(2).

8 J. Sun, Z. Yang, H. Lee and L. Wang, Simultaneous speciation and determination of arsenic, chromium and cadmium in water samples by high performance liquid chromatography with inductively coupled plasma mass spectrometry, Anal. Methods, 2015, 7, 2653-2658.

9 B. Novotnik, T. Zuliani, A. Martinčič, J. Ščančar and R. Milačič, Effective reduction of polyatomic interferences produced by high chloride and carbon concentrations in determination of $\mathrm{Cr}(\mathrm{VI})$ by FPLC-ICP-MS, J. Anal. At. Spectrom., 2012, 27, 488-495.

10 B. Novotnik, T. Zuliani, J. Ščančar and R. Milačič, The determination of $\mathrm{Cr}(\mathrm{VI})$ in corrosion protection coatings by speciated isotope dilution ICP-MS, J. Anal. At. Spectrom., 2012, 27, 1484-1493.

11 B. Novotnik, T. Zuliani, J. Ščančar and R. Milačič, Content of trace elements and chromium speciation in neem powder and tea infusions, J. Trace Elem. Med. Biol., 2015, 31, 98-106.

12 T. Zuliani, J. Ščančar and R. Milačič, The use of stable isotopes for $\mathrm{Cr}(\mathrm{VI})$ determination in silty-clay soil solution, Anal. Bioanal. Chem., 2013, 23, 7231-7240.

13 J. Ščančar, B. Berlinger, Y. Thomassen and R. Milačič, Simultaneous speciation analysis of chromate, molybdate, tungstate and vanadate in welding fume alkaline extracts by HPLC-ICP-MS, Talanta, 2015, 142, 164-169.

14 United States Environmental Protection Agency (EPA), Reduce, Reuse, Recycle, https://www.epa.gov/recycle, Last updated on January 4, 2017.

15 Official Journal of the European Union, Directive 2008/98/EC of the European Parliament and of the Council on Waste and Repealing Certain Directives, 2008, vol. 312, pp. 3-30.

16 Official Journal of the European Union, Regulation (EU) No. 305/2011 of the European Parliament and of the Council Laying Down Harmonised Conditions for the Marketing of Construction Products and Repealing Council Directive 89/ 106/EEC, 2011, vol. 88, pp. 5-43. 
17 T. Šturm, R. Milačič, S. Murko, M. Vahčič, A. Mladenovič, J. Strupi Šuput and J. Ščančar, The use of EAF dust in cement composites: assessment of environmental impact, J. Hazard. Mater., 2009, 166, 277-283.

18 NEN 7375, Netherlands Normalisation Institute Standard, Leaching characteristics of moulded or monolithic building and waste materials, Determination of inorganic components with the diffusion test, The tank test, 2004.

19 V. Zalar Serjun, A. Mladenovič, B. Mirtič, A. Meden, J. Ščančar and R. Milačič, Recycling of ladle slag in cement composites: environmental impacts, Waste Manag., 2015, 43, 376-385.

20 A. Drinčić, I. Nikolić, T. Zuliani, R. Milačič and J. Ščančar, Long-term environmental impacts of building composites containing waste materials: evaluation of the leaching protocols, Waste Manag., 2017, 59, 340-349.

21 M. Vahčič, R. Milačič, A. Mladenovič, S. Murko, T. Zuliani, M. Zupančič and J. Ščančar, Leachability of $\mathrm{Cr}(\mathrm{VI})$ and other metals from asphalt composites with addition of filter dust, Waste Manag., 2008, 28, 2667-2674.

22 T. Šturm, J. Ščančar, M. Vahčič, A. Mladenovič and R. Milačič, Environmental impacts of asphalt and cement composites with addition of EAF dust, RMZ-Mater. Geoenviron., 2011, 58, 181-192.

23 R. Milačič, T. Zuliani, T. Oblak, A. Mladenovič and J. Ščančar, Environmental impacts of asphalt mixes with electric arc furnace steel slag, J. Environ. Qual., 2011, 40, 1153-1161.

24 K. J. R. Rosman and P. D. P. Taylor, Isotopic compositions of the elements 2009 (IUPAC Technical Report), Pure Appl. Chem., 2011, 83, 397-410.

25 T. W. May and R. H. Wiedmeyer, A table of polyatomic interferences in ICP-MS, At. Spectrosc., 1998, 19, 150-155.

26 S. Langård and M. Costa, in Handbook on the Toxicology of Metals. Chromium, ed. G. F. Nordberg, B. A. Fowler, M. Nordberg and L. Friberg, Academic Press, Inc., 3rd edn, 2007, pp. 487-510.

27 B. A. Fowler, C.-H. S. J. Chou, R. L. Jones and C.-J. Chen, in Handbook on the Toxicology of Metals. Arsenic, ed. G. F. Nordberg, B. A. Fowler, M. Nordberg and L. Friberg, Academic Press, Inc., 3rd edn, 2007, pp. 367-405.

$28 \mathrm{~J}$. R. Turnlund and L. T. Friberg, in Handbook on the Toxicology of Metals. Molybdenum, ed. G. F. Nordberg, B. A. Fowler, M. Nordberg and L. Friberg, Academic Press, Inc., 3rd edn, 2007, pp. 731-741.

29 B. J.-S. Lagerkvist and A. Oskarsson, in Handbook on the Toxicology of Metals. Vanadium, ed. G. F. Nordberg, B. A.
Fowler, M. Nordberg and L. Friberg, Academic Press, Inc., 3rd edn, 2007, pp. 905-923.

30 J. Ščančar and R. Milačič, A critical overview of Cr speciation analysis based on high performance liquid chromatography and spectrometric techniques, J. Anal. At. Spectrom., 2014, 29, 427-443.

31 K. Müller, V. S. T. Ciminelli, M. S. S. Dantas and S. Willscher, A comparative study of $\mathrm{As}(\mathrm{III})$ and $\mathrm{As}(\mathrm{V})$ in aqueous solutions and adsorbed on iron oxy-hydroxides by Raman spectroscopy, Water Res., 2010, 44, 5660-5672.

32 T. Z. Minović, J. J. Gulicovski, M. M. Stoiljković, B. M. Jokić, L. S. Živković, B. Z. Matović and B. M. Babić, Surface characterization of mesoporous carbon cryogel and its application in arsenic (III) adsorption from aqueous solutions, Microporous Mesoporous Mater., 2015, 201, 271276.

33 Geological Survey of Japan Open File Report No.419, Atlas of Eh-pH diagrams. Intercomparison of thermodynamic databases, National Institute of Advanced Industrial Science and Technology Research Center for Deep Geological Environments, Naoto Takeno, 2005, pp. 149-151.

34 P. C. H. Mitchell, in Ullmann's Encyclopedia of Industrial Chemistry. Chemistry of Molybdenum, ed. M. Gerhartz, Wiley-VCH, 5th edn, 1990, vol. A16, pp. 675-682.

35 F. A. Cotton and G. Wilkinson, Advanced Inorganic Chemistry, Molybdenum and Tungsten, John Wiley \& Sons, Inc., 5th edn, 1988, pp. 804-847.

36 A. S. Tracey, G. R. Willsky and E. S. Takeuchi, Vanadium: Chemistry, Biochemistry, Pharmacology and Practical Applications, CRC Press, Taylor\&Francis Group, Boca Raton FL, USA, 2007, pp. 1-27.

37 Geological Survey of Japan Open File Report No.419, Atlas of Eh-pH Diagrams. Intercomparison of Thermodynamic Databases, National Institute of Advanced Industrial Science and Technology Research Center for Deep Geological Environments, Naoto Takeno, 2005, pp. 269-271.

38 D. C. Crans and A. S. Tracey, The Chemistry of Vanadium in Aqueous and Nonaqueous Solution, in Vanadium Compounds, Chemistry, Biochemistry, and Therapeutic Applications, the Chemistry of Vanadium in Aqueous and Nonaqueous Solution, ACS Symposium Series, American Chemical Society, 1998, vol. 711, pp. 2-29.

39 N. N. Greenwood and A. Earnshaw, Chemistry of the Elements. Vanadium, Niobium and Tantalum, Elsevier ButterworthHeinemann, Amsterdam, Netherlands, 2nd edn, 1997, pp. 976-1001. 